\title{
ORGANIC GEOCHEMISTRY OF LATE CENOZOIC SEDIMENTS FROM THE SUBTROPICAL SOUTH ATLANTIC OCEAN
}

\author{
SUSHIEL R. KESWANI, KEITH W. DUNHAM and PHILIP A. MEYERS \\ Oceanography Program, Department of Atmospheric and Oceanic Science, The University \\ of Michigan, Ann Arbor, MI 48109 (U.S.A.)
}

(Received August 23, 1983; revised and accepted January 13, 1984)

\section{ABSTRACT}

Keswani, S.R., Dunham, K.W. and Meyers, P.A., 1984. Organic geochemistry of late Cenozoic sediments from the subtropical South Atlantic Ocean. Mar. Geol., 61: $25-42$.

Organic matter has been characterized in samples of Pleistocene, Pliocene, and Miocene sediments from seven Deep Sea Drilling Project sites in the subtropical South Atlantic Ocean. Organic carbon concentrations average $0.3 \%$ for most samples, and n-alkanoic acid, n-alkanol, and alkane biomarkers indicate ex tensive microbial reworking of organic matter in these organic-carbon-lean sediments. Samples from the easternmost parts of the South Atlantic contain an average of $4.1 \%$ organic carbon and reflect the high productivity associated with the Benguela Current. Lipid biomarkers show less microbial reworking in these sediments. Eolian transport of land-derived hydrocarbons is evident at most of these oceanic locations.

\section{INTRODUCTION}

The organic carbon content of sediments is part of the oceanographic record of changes in the origins and depositional settings of sediments which have occurred over geological time. Different types of organic components and their concentrations reflect the various processes active in the accumulation and preservation of organic matter in sediments.

The objective of this study was to compare the character and amount of organic matter in Quaternary and Neogene sediments obtained from locations sampled in 1980 by Deep Sea Drilling Project Legs 72,74 and 75 in the South Atlantic Ocean (Fig.1).

These DSDP sites are located between $18^{\circ}$ and $32^{\circ} \mathrm{S}$. Sediments analyzed from these sites are of similar ages but differ in their compositions. Samples from Legs 72 and 74 represent low-productivity regions with relatively similar, low concentrations of organic carbon (Meyers and Dunham, 1983; Meyers and Keswani, 1984), whereas Leg 75 samples are from an area of high productivity associated with the Benguela upwelling system off SouthWest Africa (Hay et al., 1982; Meyers and Dunham, 1984).

Characterization and comparison of the organic geochemistry of these 


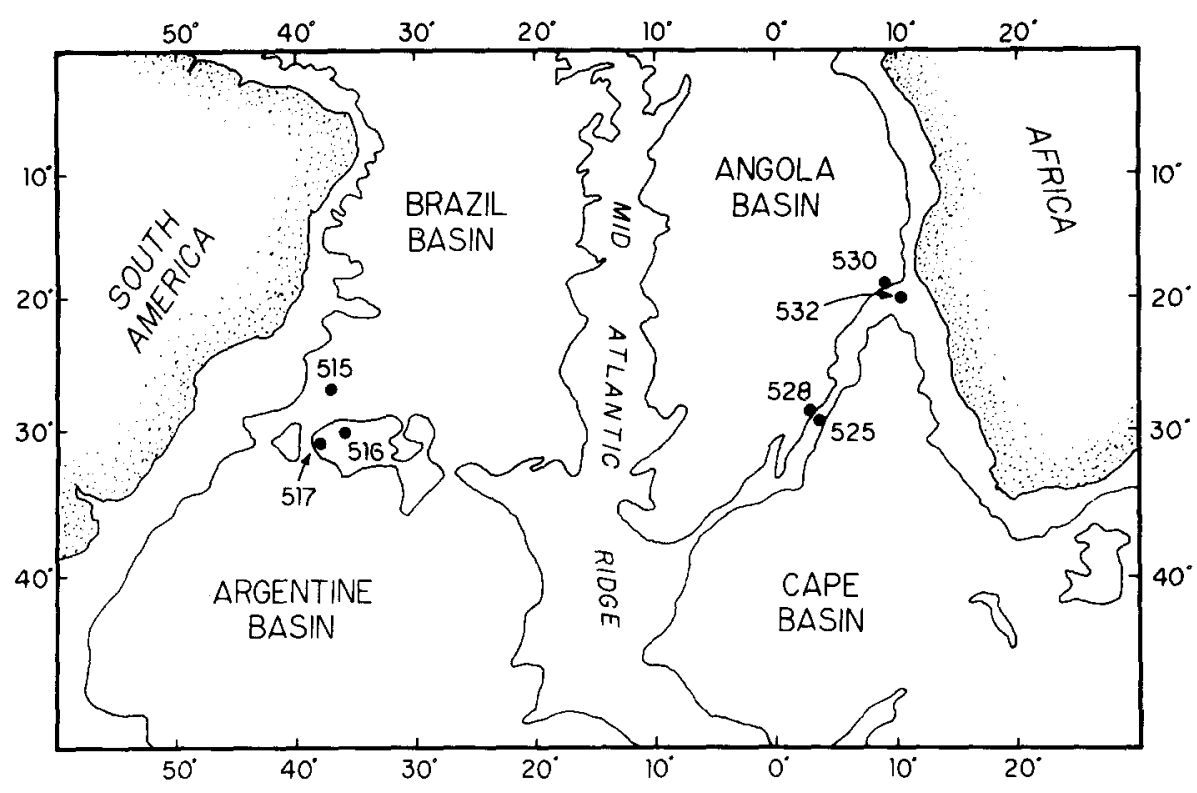

Fig.1. Locations of Leg 72 DSDP Sites 515,516 and 517 in the western South Atlantic, Legs 74 and 75 DSDP Sites 525, 528,530 and 532 in the eastern South Atlantic.

sediments contribute towards describing the paleoceanographic conditions that may have prevailed during the late Tertiary and Quaternary periods in the subtropical South Atlantic and provide information about the postdepositional diagenesis of organic matter components in marine sediments.

\section{EXPERIMENTAL}

\section{Samples and settings}

Sampling was done by D/V "Glomar Challenger" using the hydraulic piston corer and, hence, has minimal disturbance. Table I lists the ages, subbottom depths, and organic carbon contents of the samples.

\section{Leg 72 Sites - Western Atlantic}

Site 515 is at a water depth of $4250 \mathrm{~m}$ in the Brazil Basin approximately $200 \mathrm{~km}$ north of the Vema Channel. Cores obtained from this site were relatively carbonate-free as a result of deposition below the calcite compensation depth (CCD). The sections we studied were gray-brown nonfossiliferous terrigenous mud of Quaternary and late Tertiary ages. The sedimentation rate is estimated to be $2-3.5 \mathrm{~cm} / 1000$ yrs (Barker et al., 1981).

Site 516 is the shallowest site drilled on Leg 72 and is at a depth of $1313 \mathrm{~m}$ on the northwest shoulder of the Rio Grande Rise, well above the CCD. Sediments are primarily carbonate oozes and have an average sedimentation rate of about $1 \mathrm{~cm} / 1000$ yrs (Barker et al., 1981). 


\section{TABLE I}

General description and organic contents of late Cenozoic sediment samples from DSDP sites in the South Atlantic. See Fig.1 and text for descriptions of locations

\begin{tabular}{|c|c|c|c|c|c|c|c|}
\hline Hole & Core-section & $\begin{array}{l}\text { Core interval } \\
\text { (cm) }\end{array}$ & $\begin{array}{l}\text { Subbottom } \\
\text { depth } \\
\text { (m) }\end{array}$ & Age & $\% \mathrm{CaCO}_{3}$ & $\begin{array}{l}\% \text { Organic } \\
\text { carbon }\end{array}$ & $\begin{array}{l}\text { Atomic } \\
\mathrm{C} / \mathrm{N}\end{array}$ \\
\hline 515 & $2-2$ & $108-113$ & 42.1 & Quaternary & 7 & 0.43 & 9.6 \\
\hline \multirow[t]{2}{*}{$515 \mathrm{~B}$} & $3-4$ & $140-150$ & 119.8 & Pleistocene & 9 & 0.23 & 6.9 \\
\hline & $6-6$ & $145-150$ & 151.5 & Pliocene & 9 & 0.24 & 6.9 \\
\hline $516 \mathrm{~A}$ & $2-2$ & $145-150$ & 6.5 & Pleistocene & 82 & 0.13 & 4.8 \\
\hline 517 & $4-2$ & $135-141$ & 14.2 & Pleistocene & 58 & 0.28 & 19.2 \\
\hline \multirow[t]{2}{*}{$525 \mathrm{~A}$} & $6-5$ & $120-125$ & 105.8 & Late Miocene & 70 & 0.75 & 8.8 \\
\hline & $8-6$ & $120-125$ & 183.3 & Middle Miocene & 74 & 0.15 & 5.8 \\
\hline \multirow{4}{*}{$\begin{array}{l}528 \\
528 A\end{array}$} & $1-3$ & $120-125$ & 4.2 & Pleistocene & 76 & 0.38 & 8.1 \\
\hline & $5-2$ & $120-125$ & 18.8 & Pliocene & 80 & 0.20 & 10.8 \\
\hline & $14-2$ & $120-125$ & 58.4 & Pliocene & 67 & 0.21 & 3.1 \\
\hline & $23-2$ & $120-125$ & 98.0 & Late Miocene & 67 & 0.16 & 4.5 \\
\hline \multirow[t]{2}{*}{$530 \mathrm{~B}$} & 4-1 & $75-80$ & 12 & Pleistocene & 6 & 2.7 & 15.6 \\
\hline & $9-2$ & $110-120$ & 35 & Pleistocene & 15 & 1.8 & 7.8 \\
\hline \multirow[t]{2}{*}{532} & $5-2$ & $100-110$ & 20 & Pleistocene & 4 & 9.7 & 26.3 \\
\hline & $58-2$ & $80-90$ & 237 & Late Miocene & 44 & 2.1 & 16.1 \\
\hline
\end{tabular}

Site 517 is on the west flank of the Rio Grande Rise, bordering the Vema Channel at a depth of $2963 \mathrm{~m}$, close to the CCD. Sediments are primarily foraminiferal nannofossil ooze and show almost no evidence of slumping or reworking by turbidity or thermohaline currents. The sedimentation rate is $0.8-2 \mathrm{~cm} / 1000$ yrs (Barker et al., 1981).

\section{Leg 74 Sites - Walvis Ridge region}

Site 525 is on the eastern edge of the Walvis Ridge about $1000 \mathrm{~km}$ west of the South African coast in a water depth of $2467 \mathrm{~m}$, well above the CCD. The sediments are foraminiferal nannofossil oozes strongly reworked by bioturbation. The samples we analyzed range in age from middle Miocene to late Miocene with a sedimentation rate of about $1 \mathrm{~cm} / 1000 \mathrm{yrs}$ (Moore et al., 1983).

Site 528 is located about $20 \mathrm{~km}$ north of the Walvis Ridge and close to the floor of the Angola Basin in a water depth of $3800 \mathrm{~m}$ and above the CCD. The sediments are rich in carbonates and poor in opal. They are calcareous oozes that show evidence of slumping and turbidity flows. Their sedimentation rate is estimated at $1-2 \mathrm{~cm} / 1000$ yrs (Moore et al., 1983).

\section{Leg 75 Sites - Eastern Atlantic margin}

Site 530 is north of the Walvis Ridge in the southeastern Angola Basin at a depth of $4629 \mathrm{~m}$. Sediments here contain a mixture of debris-flow deposits, diatom ooze, and nannofossil ooze. These sediments have high concentrations of opal and of organic carbon, which suggest high biological productivity in surface waters. The sedimentation rate for this region is $4-6.5 \mathrm{~cm} /$ 1000 yrs (Hay et al., 1982).

Site 532 is at a water depth of $1331 \mathrm{~m}$ on the eastern part of the Walvis Ridge and close to Site 362 of DSDP Leg 40 . The sediments are siliceous 
oozes with light-to-dark alternations which may reflect episodic fluctuations in marine productivity. The darker regions contain a larger fraction of clays which may result from increased eolian input of continental material (Hay et al., 1982). Accumulation rates range between 2 and $6.5 \mathrm{~cm} / 1000 \mathrm{yrs}$ in these late Cenozoic sediments (Hay et al., 1982). The concentration patterns of organic carbon, diatom abundance, and nutrient incorporation in sediments of nearby Site 362 indicate a late Miocene onset of upwelling in this part of the South Atlantic (Diester-Haass and Schrader, 1979; Siesser, 1980).

\section{METHODS}

Samples of sediment frozen on board ship were freeze-dried and analyzed for total carbon content with a Hewlett-Packard 185 B CHN analyzer. Standards and blanks were routinely analyzed. Residual carbon was measured after $\mathrm{HCl}$ dissolution of carbonates and was considered to represent total organic carbon content. Percent calcium carbonate was calculated from the difference between initial and residual carbon contents. Organic matter $\mathrm{C} / \mathrm{N}$ atomic ratios were determined from residual carbon $\mathrm{CHN}$ values. Percent organic carbon contents of the samples were calculated on a dry weight basis for the original carbonate-containing sediments. The relative standard deviation of this organic carbon procedure is $\pm 9 \%$ (Meyers et al., 1984).

Geolipids were ex tracted from Legs 72 and 75 samples by Soxhlet extraction with 2:1 toluene/methanol. Samples from Leg 74 were shaken with toluene/methanol after being treated with $\mathrm{HCl}$ to dissolve biogenic carbonates. Extracted material was saponified and then treated with methanolic boron trifluoride to convert fatty acids to their methyl esters. Lipid subfractions were separated by column chromatography on alumina over silica gel. Classes of lipids thus obtained contained alkanes and alkenes, aromatic hydrocarbons, fatty acid methyl esters, and hydroxyl lipids including sterols and alkanols. Hydroxyl compounds were silylated with BSTFA prior to gas chromatography.

Lipid fractions were analyzed by FID gas chromatography using a $20 \mathrm{~m}$ SE54 fused silica capillary column, hydrogen as carrier gas, and splitless injection. Retention times of standards were used to identify the individual components of hydrocarbons, fatty acids, and alkanols. Reported data have been corrected for minor amounts of laboratory contamination and for the mass discrimination which occurs over the wide molecular weight ranges surveyed. Combined gas chromatography mass spectrometry was performed on selected hydrocarbon fractions to verify their identifications based on retention times.

\section{RESULTS AND DISCUSSION}

\section{Organic carbon, $C / N$ values, and mass accumulation rates}

The mean concentrations of organic carbon for Legs 72 and 74 samples are 0.26 and $0.32 \%$, respectively, and are similar to means of $0.2 \%$ for modern 
deep ocean sediments (Degens and Mopper, 1976) and of $0.3 \%$ for DSDP samples (McIver, 1975). A general decrease in concentrations of total organic carbon with depth and age exists in the data in Table I and may reflect the effect of continued degradation of organic matter observed in other DSDP samples (Rullkötter et al., 1980b; Waples and Sloan, 1980).

The low concentrations of organic carbon in samples from these two DSDP legs lead to several paleoceanographic inferences:

(1) Incorporation of organic matter into sediments occurred under oxygenated conditions, a situation unfavorable for organic matter preservation (Demaison and Moore, 1980).

(2) Low biological productivity has prevailed since the late Tertiary in the eastern and western parts of the South Atlantic Ocean (Walvis Ridge and Brazil Basin). High carbonate concentrations and consequently low opal concentrations at these locations, except Site 515 (Leg 72) which is below the CCD, suggest low biological productivity when combined with low concentrations of organic carbon (Diester-Haass, 1978).

In contrast, Leg 75 sites near the African margin record sediment accumulation under areas having high surface productivity. These sites have a mean concentration of organic carbon of $4.07 \%$, significantly above the mean values found in modern and older deep ocean sediments (McIver, 1975; Degens and Mopper, 1976).

Paleoceanographic inferences made on the basis of Leg 75 samples are:

(1) Enhanced surface biological productivity is responsible for the high opal and organic carbon concentrations in these sediments, in as much as these are two of the important indicators of surface upwelling (DiesterHaass, 1978).

(2) Improved preservation of organic matter evidently resulted from an expanded oxygen minimum zone and an enhanced flux of biogenic materials to the bottom as a consequence of the enhanced productivity.

(3) Low opal concentrations in late Miocene sediments at Site 532 which are relatively rich in organic matter may represent an early stage, which was dominated by non-siliceous organisms, in the development of upwelling in the eastern South Atlantic.

Although fluxes of organic matter to the deep sea generally decrease with increasing depth (Suess, 1980), sediments from Hole 530B at $4639 \mathrm{~m}$ in the Angola Basin contain high concentrations of organic carbon. As concluded by Hay et al. (1982) from similarities in the biogenic character of sediments from Sites 530 and 532, and from evidence of debris flows in Hole 530B sediments, downslope transfer of sediments from areas on the Walvis Ridge to the Angola Basin has occurred repeatedly. This process of downslope redistribution has resulted in deposition of sediments on the deep sea floor which have organic matter characteristics usually associated with shallower depths.

Atomic $\mathrm{C} / \mathrm{N}$ ratios can provide information about sources of total organic matter but are subject to diagenetic alteration. In general, organic particles derived from plankton have $\mathrm{C} / \mathrm{N}$ values between 5 and 8 (Müller, 1977; 
Prahl et al., 1980). During sinking of planktonic detritus, the ratios increase to reach ca. 15 in the deep sea due to preferential losses of nitrogenous components (Gordon, 1971). Unaltered material from land plants has $\mathrm{C} / \mathrm{N}$ values in the range of 15 to 30 (Müller, 1977). Based upon a survey of marine data, Premuzic et al. (1982) suggest $\mathrm{C} / \mathrm{N}$ ratios less than 8 indicate mostly marine organic matter in modern sediments and values greater than 15 show a predominance of land-derived material. With increasing time of burial, however, $\mathrm{C} / \mathrm{N}$ ratios change as a result of diagenesis. Waples and Sloan (1980) report a gradual decrease in $\mathrm{C} / \mathrm{N}$ values from ca. 10 in Quaternary sediments to ca. 4 in Miocene samples, followed by increases in older sediments. Furthermore, $\mathrm{C} / \mathrm{N}$ values tend to be high in sediments where organic matter is well-preserved (e.g., Meyers et al., 1984).

The average atomic $\mathrm{C} / \mathrm{N}$ ratios for Legs 72,74 and 75 are 6.8,9.5 and 16.4, respectively. Values of individual samples vary substantially from 3.1 to 26.3 , which may reflect diagenetic factors. Lower $\mathrm{C} / \mathrm{N}$ values indicate the greater loss of carbon relative to nitrogen (Stevenson and Cheng, 1972; Müller, 1977) or the presence of inorganic nitrogen compounds which depress the ratios in organic-lean samples (Müller, 1977).

According to the conclusions of Premuzic et al. (1982), the $\mathrm{C} / \mathrm{N}$ ratios of samples from Legs 72 (western Atlantic) and 74 (Walvis Ridge) indicate organic matter having predominantly a marine origin. Samples from Leg 75 (African margin) have values that indicate a terrigenous origin, yet marine biota are the major sources of organic matter to surface sediments in this area (Gagosian and Farrington, 1978). Because the African margin sediments contain relatively high concentrations of organic carbon, their $\mathrm{C} / \mathrm{N}$ ratios may not be reliable source indicators, but may instead record selective preservation of carbonaceous components of bulk organic matter relative to nitrogenous components.

Mass accumulation rates (MAR) were calculated from the information contained in Barker et al. (1981), Hay et al. (1982) and Moore et al. (1983). In several samples, data were incomplete, and so estimates were made based upon nearby sections from the same DSDP sites. MARs for organic carbon and for the clay mineral fraction of our samples are given in Table II. At three sites, 515 in the Brazil Basin, 530 in the Angola Basin, and 532 on the African margin, the clay MAR indicates redistributed, hemipelagic sediments. The organic carbon MARs at Sites $\mathbf{5 3 0}$ and $\mathbf{5 3 2}$ are quite high as a result of enhanced preservation of organic matter at these two locations. At the remaining four sites, clay MARs are low. All of these latter sites are on topographic highs - the Rio Grande Rise and the Walvis Ridge - and evidently receive no sediments from downslope redistribution processes.

\section{Aliphatic hydrocarbons}

Representative examples of the general distribution patterns of n-alkanes in samples from the three DSDP legs are shown in Fig.2. The patterns of samples from Legs 72 and 75 show a distinct odd-over-even predominance in which long-chain n-alkanes are major components. Hydrocarbon contributions 


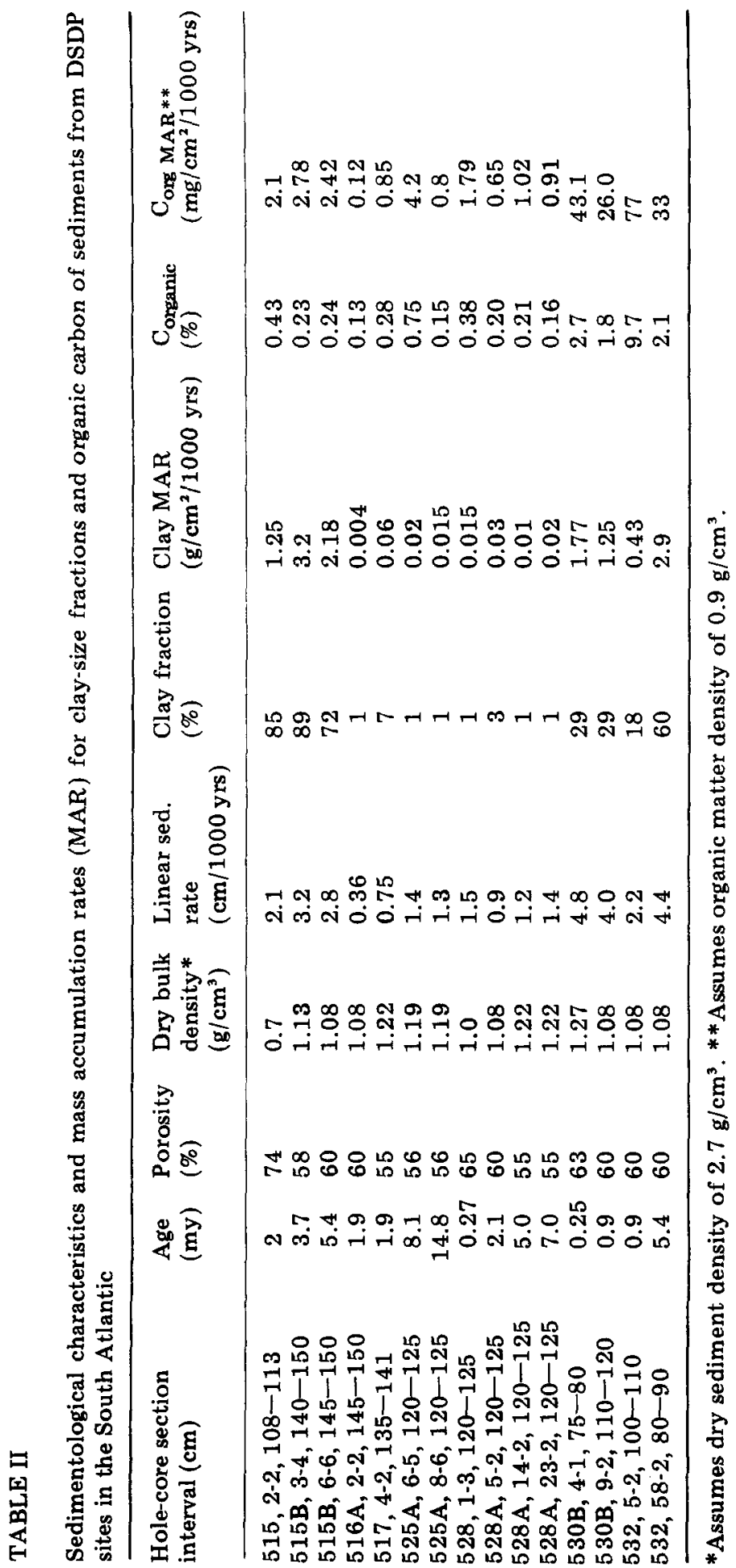




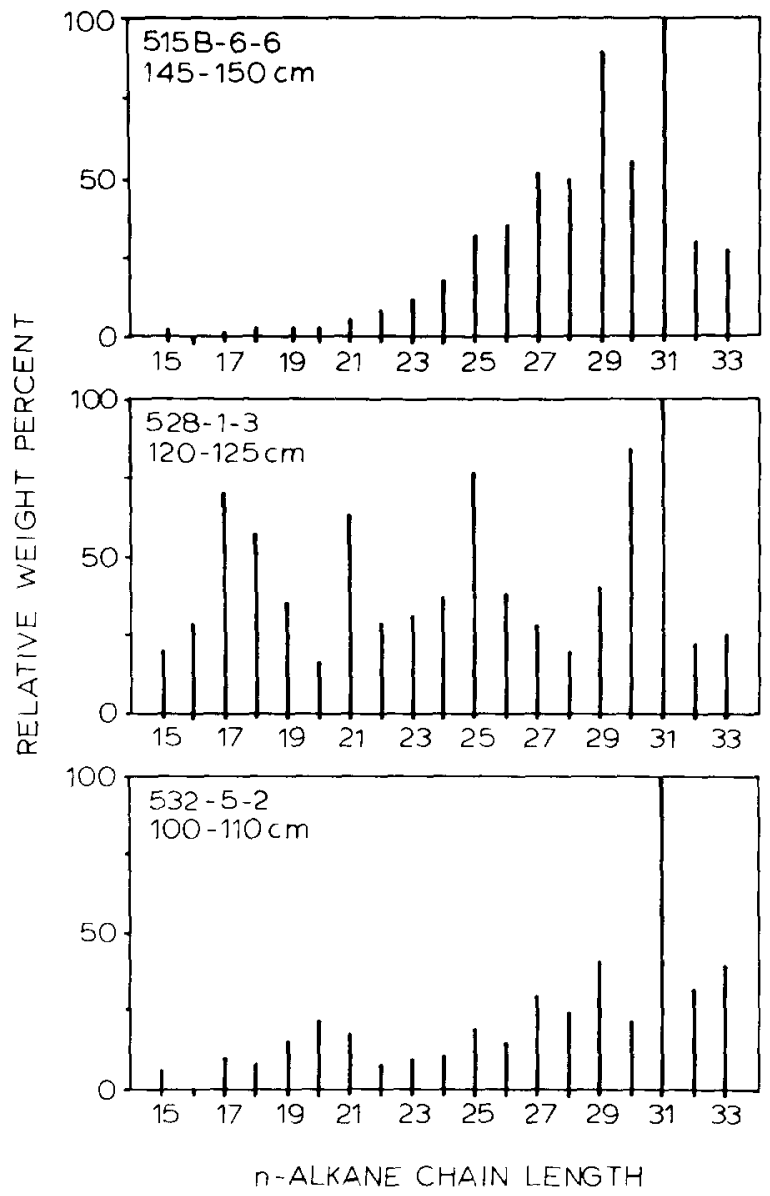

Fig. 2. General distribution patterns of $n$-alkanes from the three DSDP legs normalized to the major components (100\%). The C30 component is a mixture of $n$-triacontane and unidentified triterpenoids in $528-1-3,120-125 \mathrm{~cm}$.

attributed to land plants are dominated by C27, C29 and C31 n-alkanes while shorter chain components, such as $\mathrm{C} 15$ to $\mathrm{C} 21 \mathrm{n}$-alkanes, are attributed to algae or microbially degraded marine detritus (Simoneit, 1978a). The major n-alkanes in samples from Legs 72 and 75 are n-C29 and n-C31, respectively (Fig.2). Such terrigenous hydrocarbon distributions in Quaternary sediments have been observed at other DSDP sites (Brassell et al., 1980, 1981; Rullkötter et al., 1980a; Simoneit and Mazurek, 1981) and at locations on the MidAtlantic Ridge and in the Brazil Basin in the equatorial South Atlantic (Van Vleet and Quinn, 1979).

Downslope transport of land-derived organic material can explain the hydrocarbon distribution found in the samples from the Brazil Basin at Site 515 , but the morphology of the Rio Grande Rise decreases the likelihood of such input at Sites 516 and 517. A more likely transport process of terrigenous hydrocarbons to these locations is by eolian dusts, particularly 
in view of the abundance of terrigenous components which has been observed in the lipid extracts of dust particles collected over the Atlantic and Pacific oceans (Simoneit, 1977; Gagosian et al., 1981).

Land plant n-alkanes have two possible transport routes to the sediments at Sites 530 and $\mathbf{5 3 2}$ on the African margin. First, they may travel with the continental materials washed off Africa which contribute to the hemipelagic components of sediments at these two sites. The sparse vegetation of the coastal Namib Desert would decrease, but not eliminate, the importance of the continental runoff of organic matter. Second, the land plant hydrocarbons may originate from more humid regions in central and eastern Africa and be transported to oceanic areas by the southeast trades (cf. Simoneit, 1977). Our data do not let us evaluate the relative contributions of these two transport possibilities to these oceanic margin locations.

The hydrocarbon distributions of Leg 74 samples from the Walvis Ridge are trimodal with maxima at $\mathrm{C} 17$ or $\mathrm{C} 19$, at C25, and at C29 or C31 (Fig.2). Similar distributions have been observed in Quaternary sediments from DSDP Site 467 on the California continental borderland and have been interpreted to represent mixtures of marine and terrigenous material (Simoneit and Mazurek, 1981). Because the Leg 74 sites are on the Walvis Ridge and have low clay MARs (Table II), transport of terrigenous lipids by downslope flows is unlikely; hence, air-borne and hemipelagic transport apparently are responsible for such inputs. Comparison of n-alkane distributions in Quaternary and early Pliocene sediments at Site 528 with those of late to middle Miocene sediments from Site $\mathbf{5 2 5}$ shows a proportionally larger fraction of terrigenous components in the younger sediments (Meyers and Keswani, 1984). Because this shift in source character is contrary to that expected from diagenetic effects, it may indicate substantial modification of organic matter transport patterns in the South Atlantic since mid-Miocene times. The transport patterns may have changed in response to the growth of the Antarctic ice cap in middle to late Miocene times (Shakleton and Kennett, 1975) and accompanying modifications of the atmospheric and oceanic circulations in the southern hemisphere.

A representative chromatogram of the aliphatic hydrocarbon contents is shown in Fig.3. All the hydrocarbon fractions from Legs 72, 74 and 75 contain a substantial unresolved complex mixture (UCM) similar to the UCMs reported in Quaternary sediments from the equatorial South Atlantic by Van Vleet and Quinn (1979). Since the hydrocarbon chromatograms do not resemble those of potential shipboard contaminants (Doran and Johnson, 1979), the presence of UCMs is attributed to microbial reprocessing of sedimentary organic matter and the presence of recycled, ancient detrital organic material derived from continental erosion.

Ratios of various aliphatic hydrocarbon fractions are shown in Table III. Pristane to phytane ratios range from 0.60 to 2.00 but are usually above one. Values below one suggest anaerobic to partially euxinic bottom water conditions whereas values above one indicate aerobic depositional conditions (Didyk et al., 1978). It is unlikely, however, that the subtropical South 


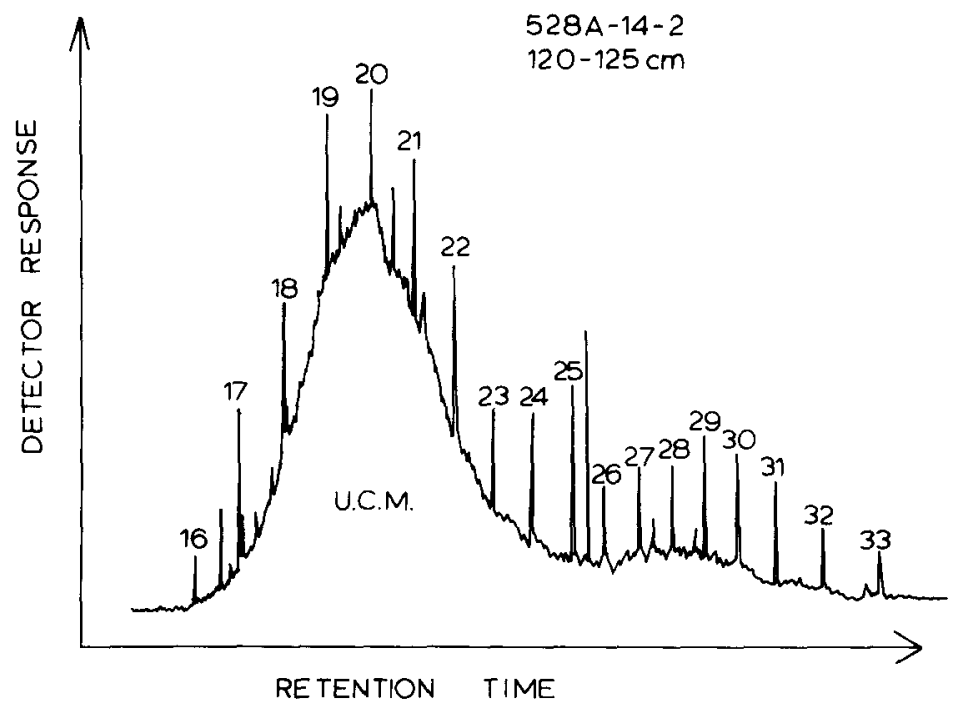

Fig. 3. A representative chromatogram of the aliphatic hydrocarbon fraction of the geolipid extract of sample 528A-14-2, 120-125 cm. Major straight chain alkanes are identified by their carbon numbers. GC conditions : $20 \mathrm{~m}$ fused silica capillary column, hydrogen carrier gas at $2 \mathrm{ml} / \mathrm{min}, 70^{\circ}-270^{\circ} \mathrm{C}$ at $4^{\circ} \mathrm{C} / \mathrm{min}$.

Atlantic became anoxic during late Tertiary or early Quaternary times, and because there appear to be significant proportions of recycled hydrocarbons from geologically older sediments in some of these samples, low pristane to phytane ratios may not accurately reflect the bottom water conditions under which these sediments accumulated and may instead be the result of microbial reworking of organic matter. Low pristane to $\mathrm{n}-\mathrm{C} 17$ values at all sites suggest microbial contributions of $\mathrm{n}-\mathrm{C} 17$ to the hydrocarbon contents of these sediments. Furthermore, lack of any systematic pattern in the ratios of $\mathrm{n}-\mathrm{C} 29$ to $\mathrm{n}-\mathrm{C} 17$, a terrigenous versus marine indicator, suggests temporal and regional variations in the degree of such microbial reworking. In addition, with the onset of northern hemisphere glacial cycles about 3 m.y. B.P. (Shackleton and Kennett, 1975), enhanced contributions of organic matter from marine productivity (Pederson, 1983) and from eolian transport of continental material (Rea and Janecek, 1982) during periods of glaciation may magnify the problems of source identification because our samples were not from sufficiently small time intervals to resolve glacial periods.

\section{n-alkanoic acids}

High values of even/odd ratios show that the total alkanoic acid extracts of samples from Legs 72,74 and 75 are dominated by even chain-length components (Table III). $\mathrm{C} 16$ and $\mathrm{C} 18$ are the major n-alkanoic acids in fractions from Leg 72, and C16 and C26 are the major n-alkanoic acids in fractions from Legs 74 and 75. Representative distribution patterns of fatty acids in these late Cenozoic sediments are shown in Fig.4. 


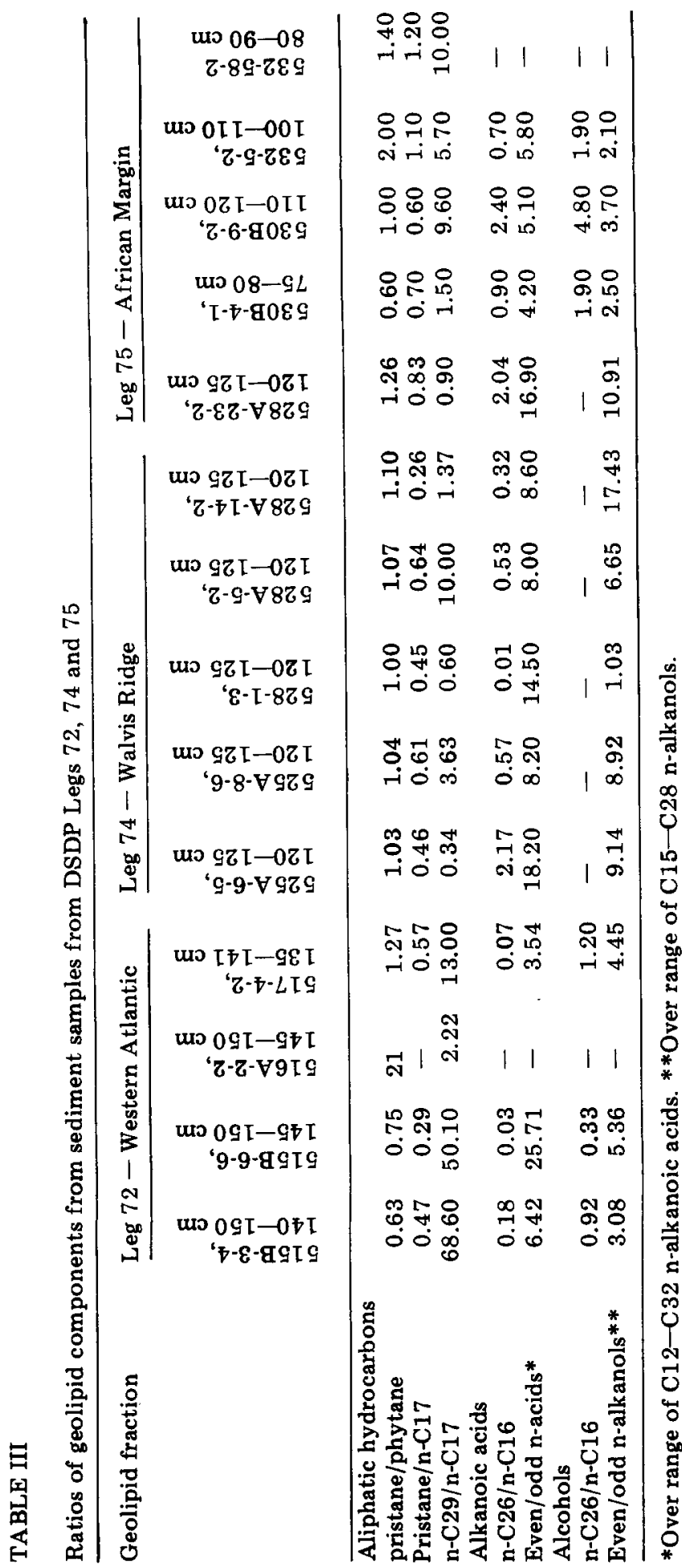



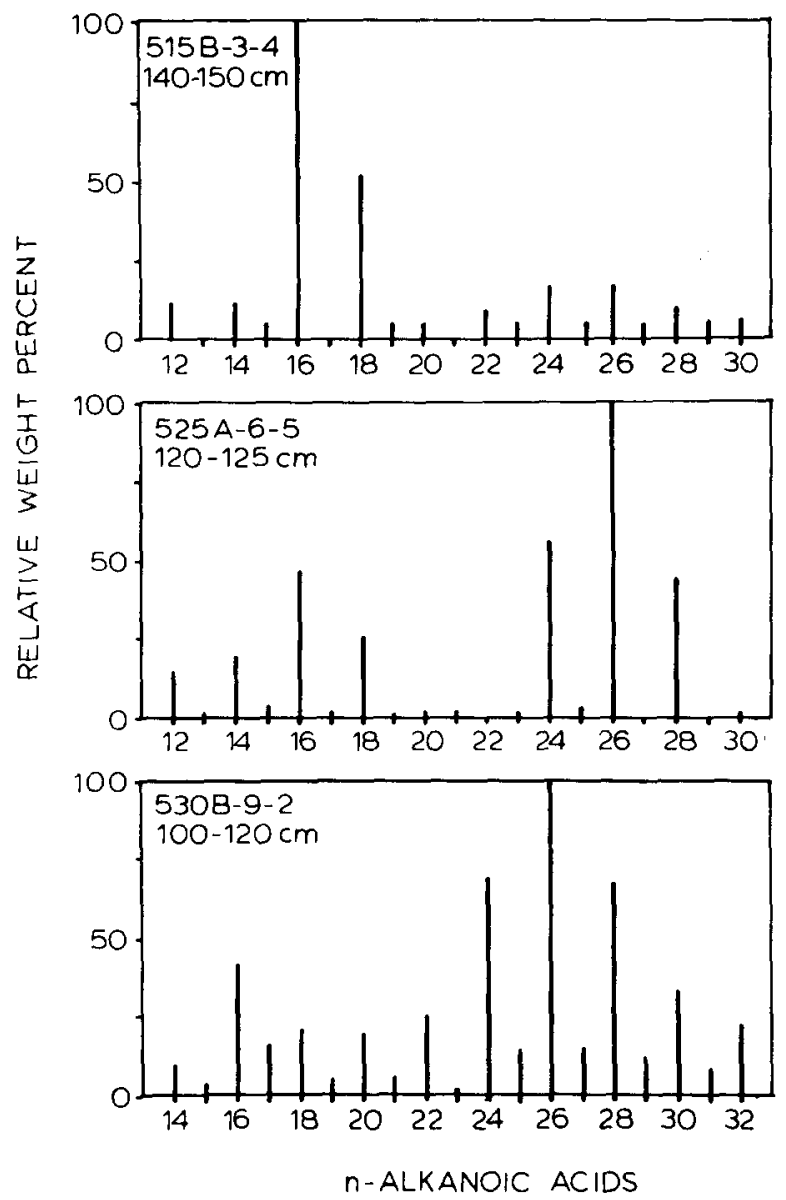

Fig.4. General distribution patterns of n-alkanoic acids from the three DSDP legs normalized to the major components.

Leg 72 samples contain relatively small contributions of long chainlength acids compared to other DSDP samples of similar ages (Meyers and Dunham, 1983). The low proportion of long chain-length acids can be attributed to extensive microbial reworking of organic matter in these sediments which were deposited under regions of low surface productivity in the western South Atlantic. Because shorter chain-length acids are more easily destroyed in sediments (Cranwell, 1981), the high proportion of $\mathrm{n}-\mathrm{C} 16$ and $\mathrm{n}-\mathrm{C} 18$ acids indicate their secondary production as a result of bacterial reworking of organic matter with accompanying extensive loss of the original character of sedimentary geolipids in these sediments.

In contrast, the n-alkanoic acid fractions in samples from Legs 74 and 75 show bimodal distributions with maxima at $\mathrm{n}-\mathrm{C} 16$ and $\mathrm{n}-\mathrm{C} 26$. The average organic carbon concentration of samples from Leg 75 is considerably higher than that from Leg 72 samples. Similar bimodal distributions of fatty acids in organic-rich samples have been observed at other DSDP sites on the Walvis 
Ridge and in the Angola Basin (Boon et al., 1978; Simoneit, 1978b) and suggests multiple biological sources of fatty acids. The n-C14, n-C16, and n-C18 components indicate algal and bacterial origin, whereas the n-C24, n-C26, and n-C28 components indicate contributions of land plants (Simoneit, 1978a). In addition to algae and bacteria, wax esters originating from diatoms may contribute to the important amounts of short chain-length acids in Leg 75 samples (Boon and DeLeeuw, 1979; Meyers and Dunham, 1984). Thus, the bimodal distributions of fatty acids in these Leg 74 and 75 sediments indicate a residuum of terrigenous long chain acids and the presence of secondary short chain acids, presumably mostly of microbial origin.

The large variability in the ratios of $\mathrm{n}-\mathrm{C} 26$ to $\mathrm{n}-\mathrm{C} 16$ acids (Table III) indicates episodic fluctuations either in relative contributions of terrigenous and marine lipid matter over time or in relative preservation of terrigenous and marine components. Due to the poor correlation between the n-C26/ $\mathrm{n}-\mathrm{C} 16$ ratios in acids and $\mathrm{n}-\mathrm{C} 29 / \mathrm{n}-\mathrm{C} 17$ ratios in alkanes, acids appear to be more sensitive to post-depositional alterations than are hydrocarbons and, hence, cannot be used as reliable source indicators. For example, the n-C29/ $\mathrm{n}-\mathrm{C} 17$ hydrocarbon ratio is high in sample 515B-3-4, 140-150 cm, but the $\mathrm{n}-\mathrm{C} 26 / \mathrm{n}-\mathrm{C} 16$ acid ratio is low, indicating a substantial original fraction of land-derived geolipid material and subsequent microbial reprocessing of fatty acids.

Comparison of the organic matter character of the four samples from Site 528 near the Walvis Ridge shows differences that appear to be related to the length of time available for diagenetic change. The samples range in age from Pleistocene to mid-Miocene (Table I). The downcore distributions of fatty acids show an increase in relative amounts of long-chain acids (Fig.5), indicating a continuing preferential loss of shorter chain-length acids over time. This change is accompanied by decreases in concentrations of organic carbon and in $\mathrm{C} / \mathrm{N}$ ratios, both of which have been reported in similarly aged sediments from other DSDP sites and have been interpreted as resulting from diagenesis (Waples and Sloan, 1980; Meyers et al., 1984).

\section{Alkanols}

As shown in the representative histograms in Fig.6, Leg 72 and 74 n-alkanols are dominated by C22 with small contributions from other alcohols. Distributions of this type may result from post-depositional reworking by microbes (Cranwell, 1981), a possibility which is consistent with the alkanoic acid data from these sites.

In contrast, Leg $75 \mathrm{n}$-alkanols are dominated by C22, C24 and C26. This $\mathrm{n}$-alkanol distribution is similar to those found at DSDP sites under or near areas of high marine productivity, including Site 362 on the African margin (Boon et al., 1978), Site 440 in the Japan Trench (Brassell et al., 1980), and Sites 487 and 491 in the Mid-America Trench (Brassell et al., 1981). A common feature of all these sites and those of Leg 75 is high organic carbon concentrations in late Cenozoic sediments. Long-chain $n$-alkanols have been 

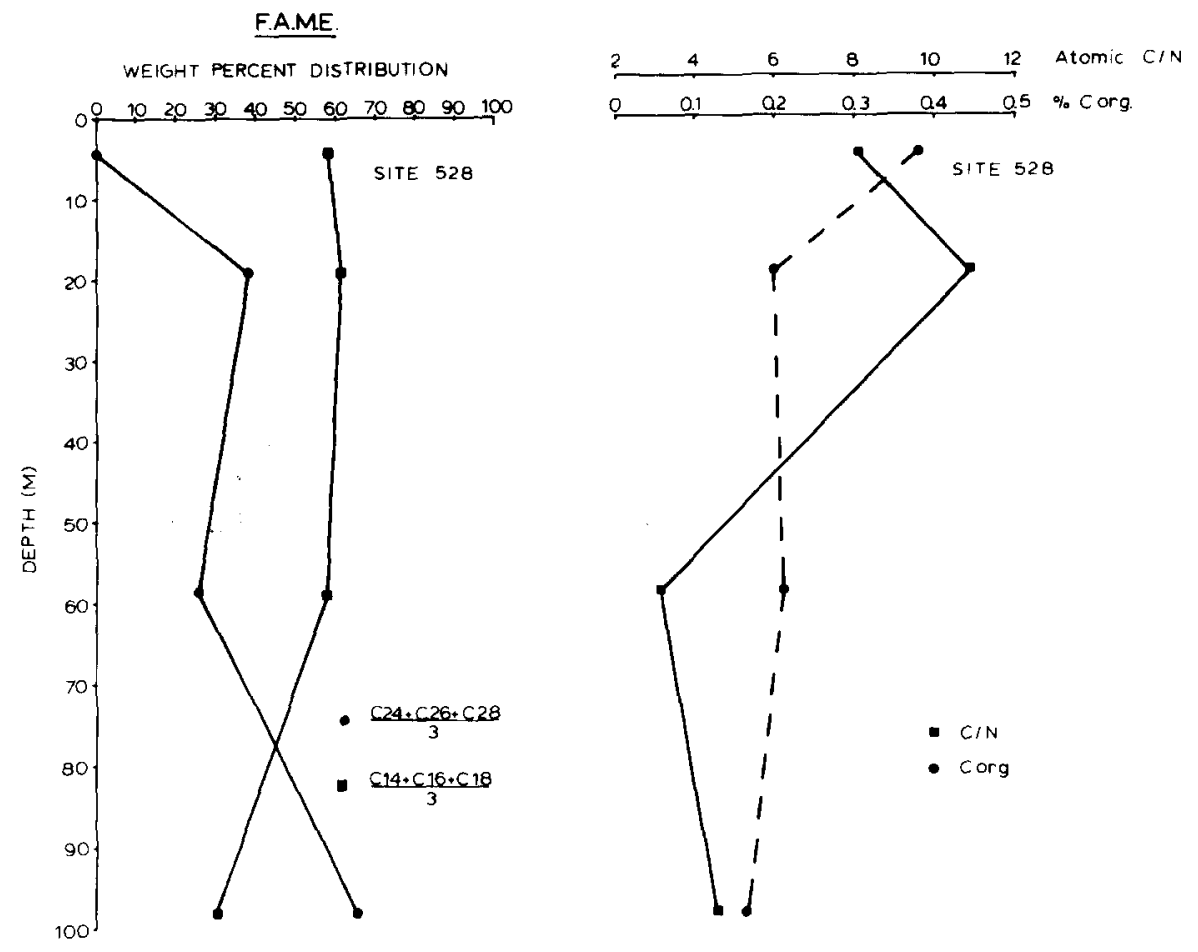

Fig.5. Downhole distributions of fatty acids, total organic carbon, and $\mathrm{C} / \mathrm{N}$ ratios at Site 528 of Leg 74 .
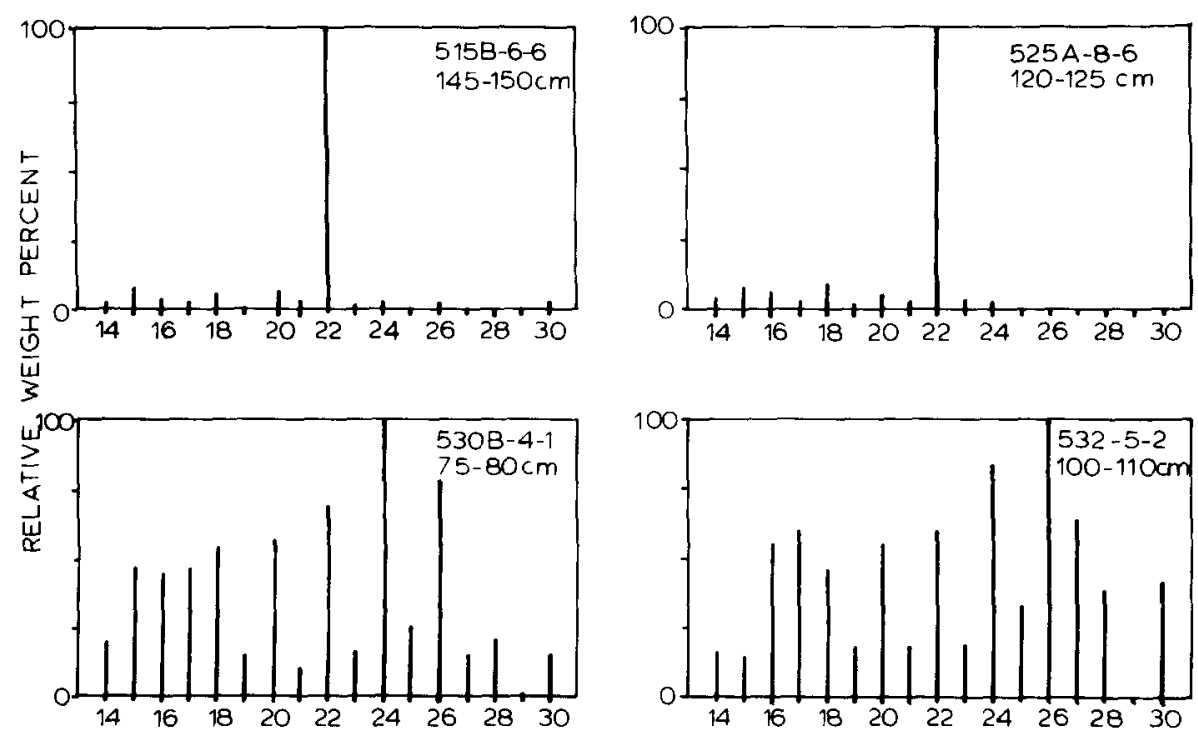

n-ALKANOL CHAIN LENGTH

Fig.6. General distribution patterns of $n$-alkanols from the three DSDP legs normalized to the major component. 
interpreted as indicators of terrigenous inputs to marine sediments (Brassell et al., 1981), and the land-derived alkanol character agrees with the $n$-alkane distributions in these Leg 75 samples (Fig.2). The presence of important amounts of long-chain lipids in sediments from areas of high marine productivity may result from better preservation of the original character of organic matter and a smaller contribution of microbial lipids. High MARs of organic matter (Table II) show that organic matter is indeed preserved better at Sites 530 and 532 than at any others in this study.

Ratios of n-C26/n-C16 and of even/odd alkanols are given in Table III. Because of the absence of long chain n-alkanols in Leg 72 and 74 samples, the $\mathrm{n}-\mathrm{C} 26 / \mathrm{n}-\mathrm{C} 16$ values are very small or not measurable. Leg 75 ratios are greater than one and show that terrigenous components dominate alkanol distributions. Even/odd ratios in Leg 72 and 74 samples are high because of the dominance of the C22 n-alkanol and indicate that the n-alkanols in all of these late Cenozoic sediment samples retain a biogenic, albeit microbial, character.

\section{CONCLUSIONS}

(1) Low concentrations of organic carbon in Pleistocene to mid-Miocene samples from Legs 72 and 74 indicate that incorporation of organic matter in these sediments occurred under conditions of oxygenated bottom water and low biological productivity. In contrast, Leg 75 samples contain high concentrations of organic carbon in Pleistocene to late Miocene sediments, evidently reflecting the enhanced productivity of the Benguela upwelling system and concomitant better preservation of organic matter.

(2) Important amounts of land-plant $n$-alkanes present in the hydrocarbon distributions indicate substantial terrigenous contributions of lipid matter to these subtropical regions of the South Atlantic. Due to the bottom morphology at sites on the Rio Grand Rise and the Walvis Ridge, eolian and hemipelagic transport are thought to be important factors in bringing continental materials to these oceanic areas.

(3) Distributions of $n$-alkanoic acids and $n$-alkanols provide evidence of extensive microbial reworking of organic components in organic-carbon-lean sediments from Legs 72 and 74 and of less microbial alteration in organiccarbon-rich sediments from Leg 75.

(4) Hydrocarbons, although also subject to diagenetic alteration, retain their source identification character better than do alkanoic acids or alkanols.

\section{ACKNOWLEDGEMENTS}

We thank E.S. Van Vleet and D.K. Rea for their suggestions for improvement of this paper. Portions of this study were supported by NSF Grant OCE 8214605. P.A.M. appreciates the opportunity to have participated in DSDP Leg 75. 


\section{REFERENCES}

Barker, P.F., Carlson, R.L., Johnson, D.A., Cepek, P., Coulbourn, W., Gamboa, L.A., Hamilton, N., Melo, U., Pujol, C., Shor, A.N., Suzyumov, A.E., Tjalsma, L.R.C., Walton, W.H. and Weiss, W., 1981. Deep Sea Drilling Project Leg 72: Southwest Atlantic paleocirculation and Rio Grande Rise tectonics. Geol. Soc. Am. Bull., Part I, 92: 294-309.

Brassell, S.C., Comet, P.A., Eglinton, G., Isaacson, P.J., McEvoy, J., Maxwell, J.R., Thomson, I.D., Tibbetts, P.J.C. and Volkman, J.K., 1980. Preliminary lipid analyses of sections 440A-7-6, 440B-3-5, 440B-8-4, 440B-68-2, and 436-11-4: Legs 56 and 57, Deep Sea Drilling Project. In: Scientific Party, Init. Rep. DSDP, Vols. 56, 57. U.S. Govt. Printing Office, Washington, D.C., pp.1367-1390.

Brassell, S.C., Eglinton, G. and Maxwell, J.R., 1981. Preliminary lipid analyses of two Quaternary sediments from the Middle America Trench, southern Mexico transect, Deep Sea Drilling Project Leg 66. In: J.S. Watkins, J.C. Moore et al., Initial Reports of the DSDP, Vol. 66. U.S. Govt. Printing Office, Washington, D.C., pp. 557-580.

Boon, J.J., Van Der Meer, F.W., Schuyl, P.J.W., DeLeeuw, J.W., Schenck, P.A. and Burlingame, A.L., 1978. Organic geochemical analyses of core samples from Site 362 , Walvis Ridge, DSDP Leg 40. In: H.M. Bolli, W.B.F. Ryan et al., Initial Reports of the DSDP, Vol. 40 (suppl.). U.S. Govt. Printing Office, Washington, D.C., pp.627-637.

Boon, J.J. and DeLeeuw, J.W., 1979. The analysis of wax esters, very long midchain ketones, and sterol ethers isolated from Walvis Bay diatomaceous ooze. Mar. Chem., 7: $117-132$.

Cranwell, P.A., 1981. Diagenesis of free and bound lipids in terrestrial detritus deposited in a lacustrine sediment. Org. Geochem., 3: 79-89.

Degens, E.T. and Mopper, K., 1976. Factors controlling the distribution and early diagenesis of organic material in marine sediments. In: J.P. Riley and R. Chester (Editors), Chemical Oceanography, V6. Academic Press, New York, N.Y., pp. 59-113.

Demaison, G.J. and Moore, G.T., 1980. Anoxic environments and oil source bed genesis. Org. Geochem., 2: 9-31.

Didyk, B.M., Simoneit, B.R.T., Brassell, S.C. and Eglinton, G., 1978. Organic geochemical indicators of paleoenvironmental conditions of sedimentation. Nature, 272: 216-222.

Diester-Haass, L., 1978. Sediments as indicators of upwelling. In: R. Boje and M. Tomczak (Editors), Upwelling Ecosystems. Springer, Berlin, pp.261-281.

Diester-Haass, L. and Schrader, H.J., 1979. Neogene coastal upwelling history off Northwest and Southwest Africa. Mar. Geol., 29: 39-53.

Doran, T. and Johnson, P.G., 1979. Examination of potential geochemical contaminants in Leg 48 material. In: L. Montadert, D.G. Roberts et al., Initial Reports of the DSDP, Vol. 48. U.S. Govt. Printing Office, Washington, D.C., pp.1157-1160.

Gagosian, R.B. and Farrington, J.W., 1978. Sterenes in surface sediments from the southwest African shelf and slope. Geochim. Cosmochim. Acta, 42: 1091-1101.

Gagosian, R.B., Peltzer, E.T. and Zafiriou, O.C., 1981. Atmospheric transport of continentally derived lipids in the tropical north Pacific. Nature, 291: 312-314.

Gordon, D.C., 1971. Distribution of particulate organic carbon and nitrogen at an oceanic station in the Central Pacific. Deep-Sea Res., 18: 1127-1134.

Hay, W.W., Sibuet, J.C., Barron, E.J., Boyce, R.E., Brassell, S., Dean, W.E., Huc, A.Y., Keating, B.H., McNulty, C.L., Meyers, P.A., Nohara, M., Schallreuter, R.E., Steinmetz, J.C., Stow, D. and Stradner, H., 1982. Sedimentation and accumulation of organic carbon in the Angola Basin and on the Walvis Ridge: Preliminary results of DSDP Leg 75. Geol. Soc. Am. Bull., 23: 1038-1050.

McIver, R., 1975. Hydrocarbon occurrences from JOIDES Deep Sea Drilling Project. Proc. Ninth World Pet. Congress, pp.269-280.

Meyers, P.A. and Dunham, K.W., 1983. Organic geochemistry of Quaternary sediments from DSDP Leg 72, South Atlantic Ocean. In: P.F. Barker, R.L. Carlson et al., Initial Reports of the DSDP, Vol. 72. U.S. Govt. Printing Office, Washington, D.C., pp. 833-839. 
Meyers, P.A. and Dunham, K.W., 1984. Geolipid Comparison of biogenic sediments from Deep Sea Drilling Project Holes 530B, Angola Basin, and 532, Walvis Ridge. In: W.W. Hay, J.-C. Sibuet et al., Initial Reports of the DSDP, Vol. 75. U.S. Govt. Printing Office, Washington, D.C., in press.

Meyers, P.A. and Keswani, S.R., 1984. Organic Geochemistry of Neogene Walvis Ridge sediments from Deep Sea Drilling Project Leg 74. In: T.C. Moore, P.D. Rabinowitz et al., Initial Reports of the DSDP, Vol. 74. U.S. Govt. Printing Office, Washington, D.C., pp. 731-736.

Meyers, P.A., Brassell, S.C. and Huc, A.Y., 1984. Geochemistry of organic carbon in South Atlantic sediments from Deep Sea Drilling Project Leg 75. In: W.W. Hay, J.-C. Sibuet et al., Initial Reports of the DSDP, Vol. 75. U.S. Govt. Printing Office, Washington, D.C., in press.

Moore, T.C., Rabinowitz, P.D., Boersma, A., Borella, P.E., Chave, A.D., Duee, G., Futterer, D.K., Jiang, M.J., Keinert, K., Lever, A., Manivit, H., O'Connell, S., Richardson, S.H. and Shackleton, N.J., 1983. The Walvis Ridge transect, Deep Sea Drilling Project Leg 74: The geologic evolution of an oceanic plateau in the south Atlantic Ocean. Geol. Soc. Am. Bull, 94: 907-925.

Müller, P.J., 1977. C/N ratios in Pacific deep sea sediments: effects of inorganic ammonium and organic nitrogen compounds sorbed by clays. Geochim. Cosmochim. Acta, 41: 765-776.

Pederson, T.F., 1983. Increased productivity in the eastern equatorial Pacific during the last glacial maximum (19,000 to 14,000 yr B.P.) Geology, 11: 16-19.

Prahl, F.G., Bennett, J.T. and Carpenter, R., 1980. The early diagenesis of aliphatic hydrocarbons and organic matter in sedimentary particles from Dabob Bay, Washington. Geochim. Cosmochim. Acta, 44: 1967-1976.

Premuzic, E.T., Benkovitz, C.M., Gaffney, J.S. and Walsh, J.J., 1982. The nature and distribution of organic matter in the surface sediments of world oceans and seas. Org. Geochem., 4: 63-77.

Rea, D.K. and Janecek, T.R., 1982. Late Cenozoic changes in atmospheric circulation deduced from North Pacific eolian sediments. Mar. Geol., 49: 149-167.

Rullkötter, J., Cornford, C., Flekken, P. and Welte, D.H., 1980a. Organic geochemistry of sediments cored during Deep Sea Drilling Project Legs 56 and 57, Japan Trench: Organic petrography and extractable hydrocarbons. In: Scientific Party, Initial Reports of the DSDP, Vols. 56, 57. U.S. Govt. Printing Office, Washington, D.C., pp.12911304.

Rullkötter, J., Flekken, P. and Welte, D.H., 1980b. Organic petrography and extractable hydrocarbons from the northern Philippine Sea, Deep Sea Drilling Project, Leg 58. In: G. deV. Klein, K. Kobayashi et al., Initial Reports of the DSDP, Vol. 58. U.S. Govt. Printing Office, Washington, D.C., pp.755-762.

Siesser, W.G., 1980. Late Miocene origin of the Benguela upswelling system off northern Namibia. Science, 208: 283-285.

Shackleton, N.J. and Kennett, J.P., 1975. Paleotemperature history of the Cenozoic and the initiation of Antarctic glaciation: Oxygen and carbon isotope analysis in DSDP Sites 277, 279, and 281. In: J.P. Kennett, R.E. Houtz et al, Initial Reports of the DSDP, Vol. 29. U.S. Govt. Printing Office, Washington, D.C., pp.743-755.

Simoneit, B.R.T., 1977. Organic matter in eolian dust over the Atlantic Ocean. Mar. Chem., $5: 443-464$.

Simoneit, B.R.T., 1978a. The organic geochemistry of marine sediments. In: J.P. Riley and R. Chester (Editors), Chemical Oceanography, Vol. 7. Academic Press, London, pp. 233-311.

Simoneit, B.R.T., 1978b. Lipid analysis of sediments from Site 364 in the Angola Basin, DSDP Leg 40. In: H.M. Bolli, W.B.F. Ryan et al., Initial Reports of the DSDP, Vol. 40. U.S. Govt. Printing Office, Washington, D.C., pp.659-662. 
Simoneit, B.R.T. and Mazurek, M.A., 1981. Organic geochemistry of sediments from the southern California Borderland, DSDP Leg 63. In: R.S. Yeats, B.U. Haq et al., Initial Reports of the DSDP, Vol. 63, U.S. Govt. Printing Office, Washington, D.C., pp.837853.

Stevenson, F.J. and Cheng, C.N., 1972. Organic geochemistry of the Argentine Basin sediments: Carbon-nitrogen relationships and Quaternary correlations. Geochim. Cosmochim. Acta, 36: 653-671.

Suess, E., 1980. Particulate organic carbon flux in the oceans: surface productivity and oxygen utilization. Nature, 288: 260-263.

Van Vleet, E.S. and Quinn, J.G., 1979. Diagenesis of marine lipids in ocean sediments. Deep-Sea Res., 26A: 1225-1236.

Waples, D.W. and Sloan, J.R., 1980. Carbon and nitrogen diagenesis in deep sea sediments. Geochim. Cosmochim. Acta, 44:1463-1470. 